\title{
Changes in the production and use of pottery from the Early Neolithic to the 'secondary products revolution': some evidence from LN Makriyalos, Northern Greece
}

\author{
Dimitrios Vlachos \\ Department of Archaeology and Prehistory, University of Sheffield, UK \\ prp00dv@sheffield.ac.uk \& dimv@ @ist.auth.gr
}

\begin{abstract}
Recent developments in pottery studies have altered the way archaeologists handle and interpret prehistoric pottery. The technology and use of pottery, the symbolic and social meaning of the pot are considered as anthropological phenomena, the products of human action. Excavations at Late Neolithic Makriyalos offered the opportunity to explore from a new perspective several aspects of neolithic society in Greece in terms of the use, function, distribution and discard of pottery.
\end{abstract}

IZVLEČEK - Sodoben razvoj preučevanja keramike je spremenil način arheološke obravnave in interpretacije prazgodovinske keramike. Tehnologijo in uporabo keramike, simboličen in družbeni pomen posod smatramo za antropološki fenomen, za proizvod človekove dejavnosti. Izkopavanja poznoneolitskega Makriyalosa so omogočila nove poglede na neolitsko družbo v Grčiji z vidika uporabnosti, namenskosti, distribucije in zavrženosti lončenine.

KEY WORDS - Neolithic; Thessaly; pottery use; production; function; discard

\section{LATE NEOLITHIC MAKRIYALOS: A CASE STUDY}

In 1992 a rescue excavation in Pieria, Northern Greece, near the modern village of Makriyalos, revealed a prehistoric site with archaeological finds dated to the Late Neolithic period (Fig. 1). The site covers approximately 50 ha, of which 6 ha was intensively investigated (Pappa and Besios 1999.179). The excavation of the site offered valuable information about the character of the flat-extended type of Neolithic site, which is relatively unknown for Greece in comparison with other regions of Europe and the Balkans, where flat-extended settlements are fairly well known. The main characteristics of these settlements are the horizontally shifting occupation, interspersed with open spaces, presumably cultivated land and fields, and, finally, their great extent which may exceed 50 ha (Andreou, Fotiadis and Kotsakis 1996.578).

The excavation revealed, according to pottery finds, two different occupation episodes, Makriyalos I and
II (Fig. 2), which refer respectively to the early and late Late Neolithic. Makriyalos I is dated no earlier than $5400 \mathrm{BC}$, while Makriyalos II yielded a great amount of pottery that has close relations with decorative motifs from pottery assemblages of Thessaly, those of the so called 'Classical Dimini' pottery style (Theocharis 1973; 1993) (Figs. 3, 4). These two different occupation episodes appear on opposite slopes of the hill. Only a few sherds of Makriyalos II were found in deposits of Makriyalos I, leading to the conclusion that Makriyalos I was completely abandoned before the establishment of Makriyalos II.

During Makriyalos I, the entire settlement was encircled by two curved, parallel ditches, ditch Alpha and ditch Beta, while a third one, ditch Gamma, was revealed inside the settlement. Makriyalos II is rather different. Spatial overlap with Makriyalos I is minimal and Makriyalos II is possibly smaller in extent than Makriyalos I. In this occupational phase, 


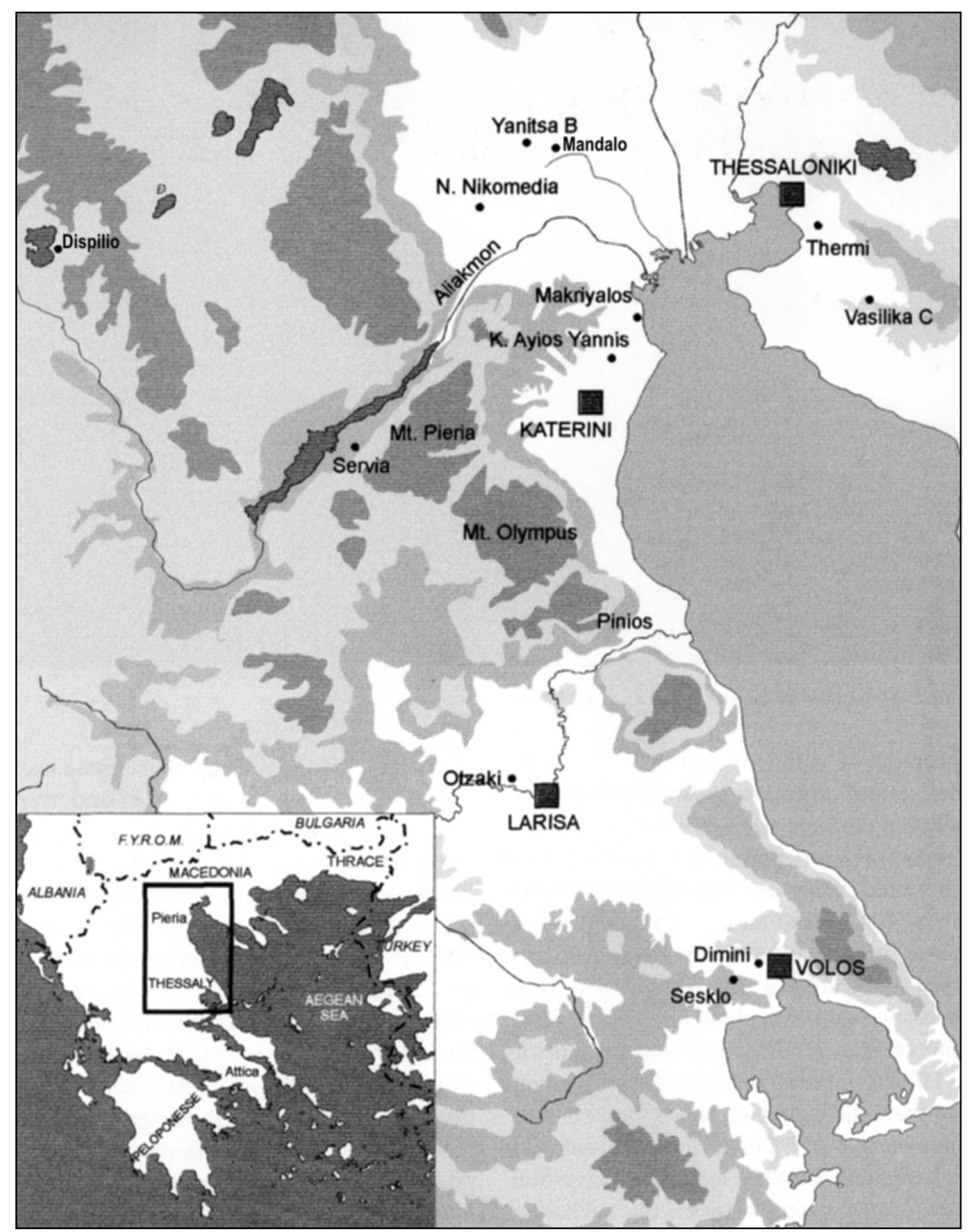

Fig. 1. Map of Pieria and Thessaly, showing sites mentioned in the text (after Pappa and Besios 1999).

ditches were also present, but their character is unclear, because they lie outside the excavated area. As in Makriyalos I, the ditches are comprised of a chain of pits forming a linear boundary to the settlement. At the intra-site level, habitation is denser in Makriyalos II with almost no open spaces between the dwellings. According to the excavators, two habitation subphases were distinguished, an earlier subphase of pit dwellings and a later subphase of apsidal structures (Pappa and Besios 1999.180). Hearths and ovens were situated outside the houses in small clusters of three or four, while a number of pits around the dwellings were recognised as storage pits, refuse pits and possible working areas.

\section{MAKRIYALOS IN PERSPECTIVE: THE POTTERY}

Understanding of the Greek Neolithic is still dominated by the results of excavations in the early $20^{\text {th }}$ century at Sesklo and Dimini (Tsountas 1908), in Thessaly. Apart from these two sites, adequate pub- lished information is scarce for settlements of this period and the same is true for pottery. Indeed, one of the major problems of Greek Neolithic studies is the restricted extent of later $20^{\text {th }}$ century excavation programmes, mostly by German and Greek groups (Gallis 1979) and, as a result, the limited potential for reliable archaeological inferences. Furthermore, most sites in Thessaly are tellvillages that were densely inhabited, long-lived and restricted in extent, and so not representative of the newly recognised category of flat-extended settlements.

Until recently the chronological framework for the Greek Neolithic and the culture histories of different regions within Greece were based on typological differences between pottery groups, analysed at an inter-site level and treating date as the only significant source of variability at an intra-site level (Milojčić 1960; Milojčić et al. 1976; Hauptmann 1981). This framework now seems fragile and the mere observation and description of typological differences inadequate. Makriyalos offers the opportunity to investigate spatial variability in archaeological material on a large scale and, thereby, to explore human activity within an early farming community with a high degree of confidence.

Among the wealth of finds from Late Neolithic Makriyalos the pottery from Makriyalos II amounts to approximately 12 tons. Information on production of the Makriyalos II pottery and the exchange of this material over long distances will be available in short time from Elli Hitsiou's study, based on thin section petrography, of certain technological aspects and provenance. The objectives of the study were to trace the social and functional role of the Makriyalos II pottery, by exploring its use and the spatial distribution of discard. In addition, it was hoped that ceramic analysis would help to refine the chronological framework of the site.

The preliminary results presented here are based on 8-months of systematic work dealing with approximately 2 tons of pottery. Sampling of material for study has focussed on the 'closed' excavation units, 


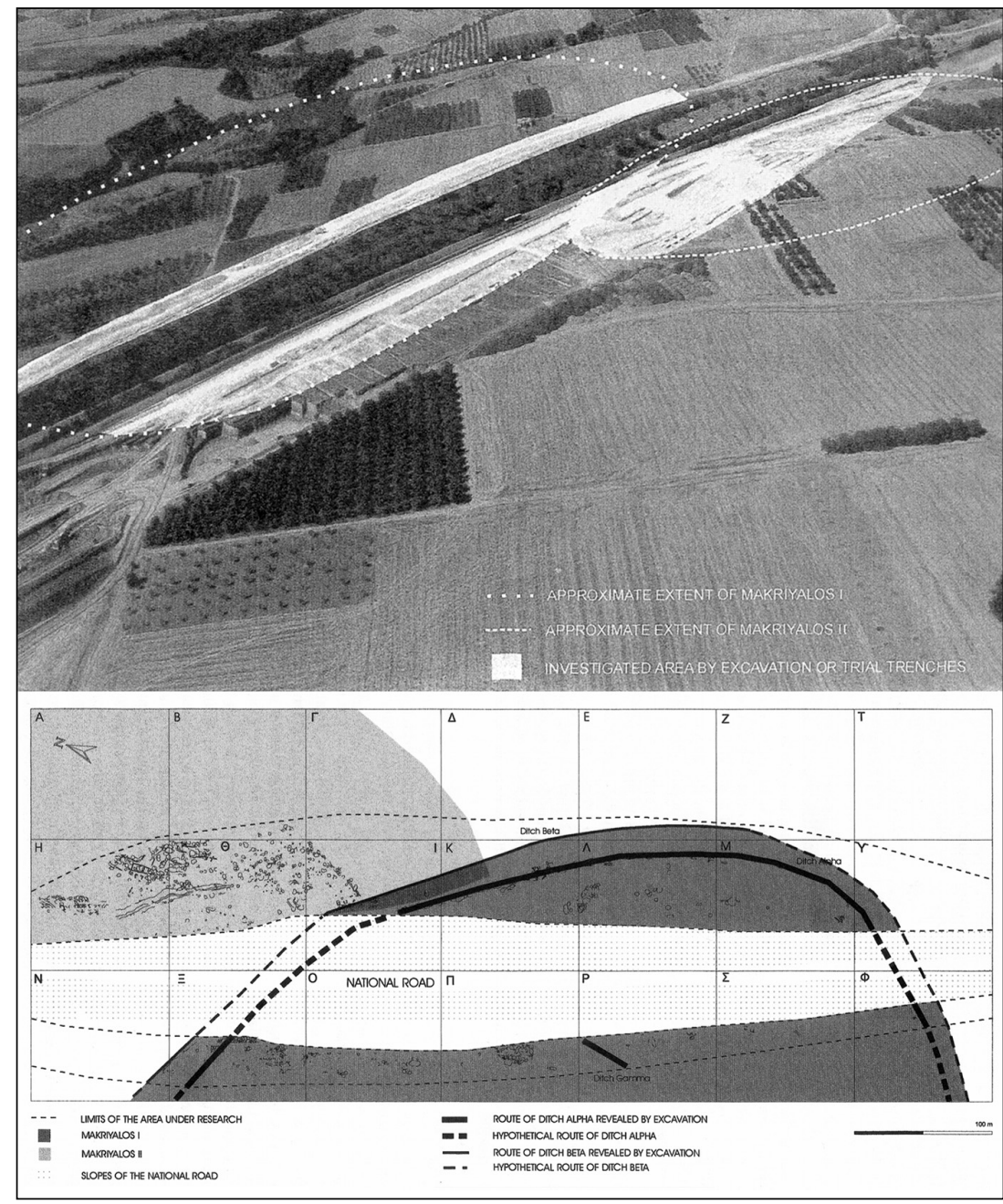

Fig. 2. Aerial view and sketch plan of Makriyalos I and II. term storage pithoi and other small storage pots; and, finally, d) for cooking pots with traces of repeated use on fire. Spatial distribution within the settlement, however, suggests variability in the use of space and/or date.

Most striking is the distribution of the so-called 'Classical Dimini' pottery style (Dimini brown-on-cream, Otzaki blackon-red, polychrome decoration and incised patterns). Almost $90 \%$ of this type of pottery comes from the ceramicrich area in sector Eta on the northern edge of the settlement, discussed above, and ca. $10 \%$ from pit 24 , which was recognised by the excavators as a clear example of a subterranean dwelling (Fig. 7). In addition, one pit outside the ditch produced a significant amount of this kind of pottery, but otherwise only a few sherds were found inside and outside the remaining pits. the pits, which, with the exception of the two or three apsidal buildings, were the basic architectural units of this phase. Almost all the material from the Makriyalos II pits was examined and recorded. In addition, some of the overlying surface layer was examined to investigate its relationship with the pits and to explore postdepositional factors that may have affected the way pottery was distributed in the archaeological record. Finally, particular attention was paid to an area in excavation sector Eta $(\mathrm{H})$, on the northern edge of the settlement, where the excavators had noted an exceptional abundance of ceramics: this area, although only one tenth of the excavated Makriyalos II habitation area, yielded nearly one quarter of the total pottery assemblage for this phase.

The most common shapes in Makriyalos II are (Figs. 5, 6): a) for tableware shallow flat-based bowls, straight-sided open bowls, carinated bowls, fruit-stands and cups; b) for serving, storing and transferring liquids jugs and jars with vertical handles; c) for long-
The excavators describe the ceramic-rich area in sector Eta as a 'borrow pit' and have suggested that this was subsequently filled with pottery eroded from the slope above the pit (Pappa and Besios 1999. 188). In support of this interpretation, the stratigraphy in this area shows a series of deposits of, sometimes, very distinctive pottery, which are separated by thin layers of soil. Beneath these deposits, were discovered some pits with small amounts of pottery and a few traces of minor ditches. If the overlying material had been deposited by erosion, however, relatively intense abrasion and fragmentation of sherds might be expected, whereas in fact the pottery is mostly well preserved and the size of sherds is remarkably large compared to other areas of the settlement.

Furthermore, as already noted, tableware in this area is overwhelmingly of 'Classical Dimini' type. Shallow flat-based bowls and straight-sided open bowls are dominant and decorated with the characteristic 'Classical Dimini' motifs, as are the fruit-stands (Fig. 8). 


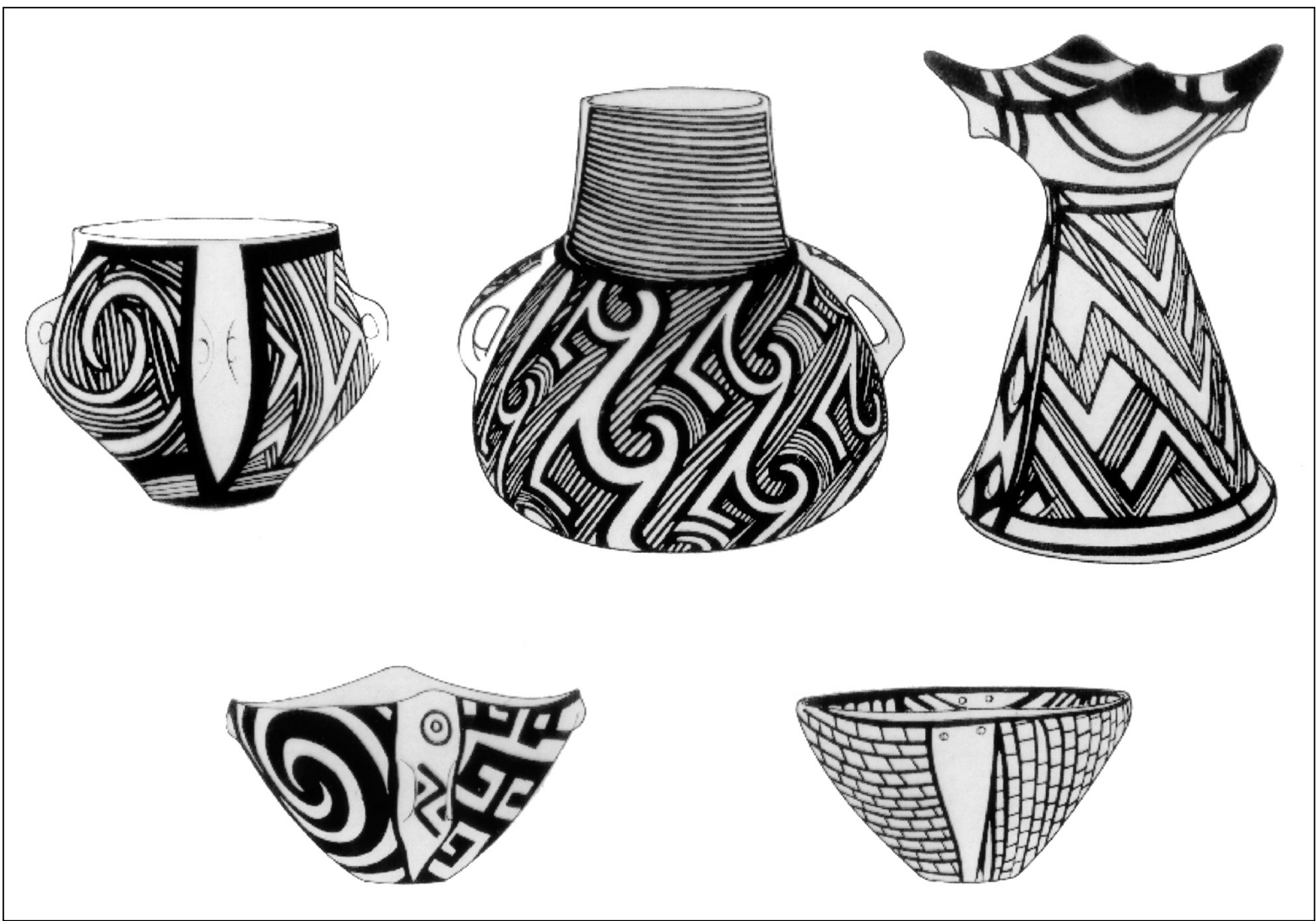

Fig. 3. 'Classical Dimini' pottery from Thessalian sites.

Some incised jars are also present. Pottery with different decorative motifs is scarce, as is undecorated tableware like cups or carinated bowls. The unusual nature of the assemblage from this area suggests that it represents the primary locus of discard from a particular human activity, rather than the result of postdepositional erosion.

Further support for this view comes from the evidence for cooking vessels in the Makriyalos II settlement. Overall, very few sherds could be associated with cooking and in most cases they were situated near cooking facilities, such as hearths. Both inside and outside the pits, sherds that could be assigned to cooking vessels or that seemed to have traces of repeated use on fire are almost absent and the few exceptions belong to fragmentary 'dish-like' vessels with rough surface, which are very shallow and have a large rim diameter. In the sector Eta 'borrow pit', however, numerous cooking vessels and pots with clear traces of fire were recognised and almost all of these have fabrics rich in shell inclusions. A very large number of

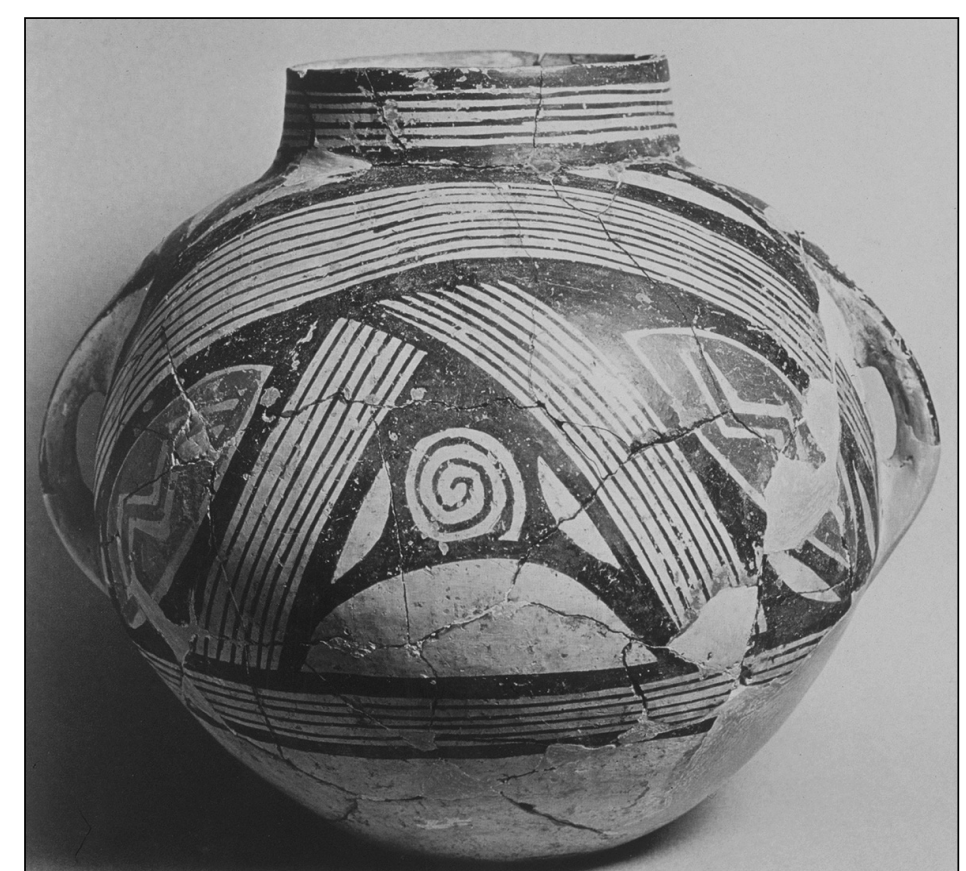

Fig. 4. Pottery with polychrome decoration. 


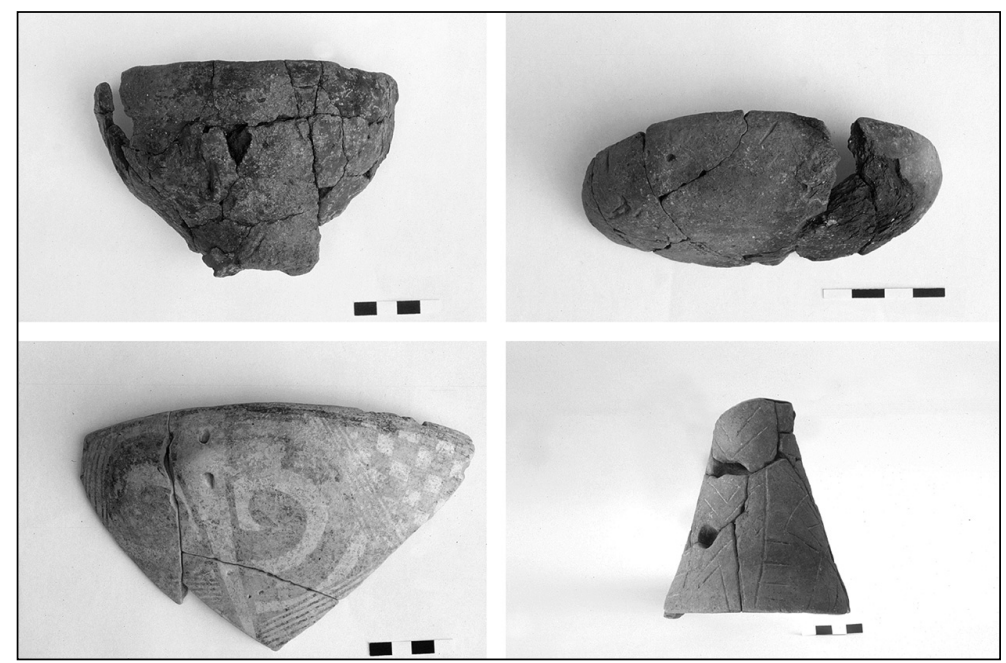

Fig. 5. Common shapes from Makriyalos II.

in the settlement and the quantity of this pottery in this 'borrow pit,' completed with the abundance in this pit of pottery related to cooking, suggest that this distinctive group of material should be interpreted in terms of patterns of activity or discard rather than chronological variation.

In the Makriyalos II habitation area, no stratigraphic distinctions are evident within pits (Fig. 9), but many pits contain small quantities of pottery and share a common, but limited 'repertoire' of ceramic categories. This 'repertoire' consists of a small number of impressed and incised tableware vessels such as carinated bowls (Fig. 10), but other tableware is undecorated and could be related to the consumption of food or liquids, as in the case of cups. Pottery for storage needs, like pithoi and small storage vessels, and for the transfer of liquids, like jars, was dominant inside the pits. Very few sherds could be ascribed to a cooking vessel, with a preference to the shallow 'dish-like' vessels. More cooking vessels were recognised in areas near hearths, but the number is still low compared to the number of cooking vessels that was found in the 'borrow pit' in sector Eta. A pit in the eastern part of the settlement yielded remarkable quantities of incised pottery, but it was excavated in a trial trench and so its spatial relationship to other pits remains unclear.

In the southern part of the excavated area, the quantity of pottery from the boundary ditch is very small, the degree of preservation extremely low and the fragmentation of sherds very high. The fill consists of sherds ascribed to small storage pots and almost complete absence of tableware or decorated pottery, except for some incised pots, as in the case of most pits at the habitation area. It seems that the pits which constituted the ditch filled with material exposed for a long time before incorporation in the ditch or in some cases with refuse discarded from the settlement itself.

The apsidal buildings (Fig. 11), assigned by the excavators to a separate habitation episode, show clear evidence of a distinctive use, even if there is heavy erosion in this area and it is very difficult to explore and interpret them. Their internal organisation, including one or two separate rooms and an apsidal end with many fragments of storage pots, reflects a different and more elaborate perception of the use of space from that of the simple pit dwellings. However, inside the rooms differences from the pit dwellings in the composition of pottery is minimal.

The subterranean dwelling, Pit 24, is the only pit that presents stratigraphic differences (Fig. 12). This pit is unusual in its depth, its diameter, the entrance identified by the excavators and the discovery of three holes marking the position of storage pots on the floor, $2 \mathrm{~m}$ below the present surface. The sherds of these storage pots were found in the floor deposit. The excavators suggest that the bottom of the pit could have been used as a cellar. The pottery of the pit exhibits a clear stratigraphic sequence. 'Classical

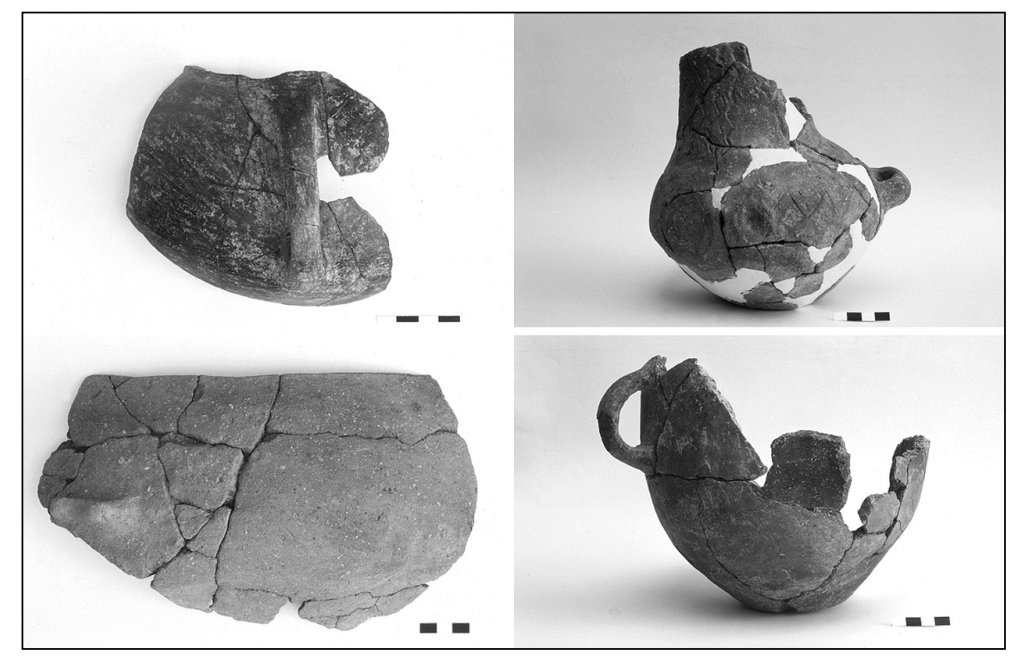

Fig. 6. Pottery from Makriyalos II. 


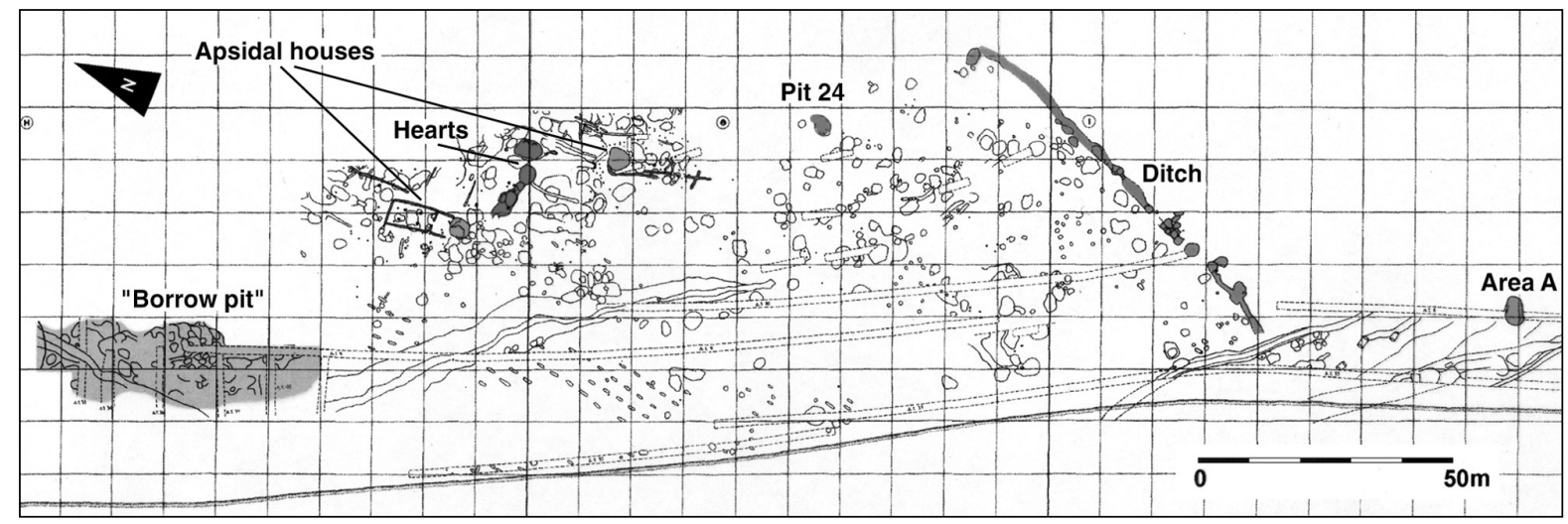

Fig. 7. Plan of Makriyalos II marking places of interest as mentioned in the text.

Dimini' pottery is dominant in the upper layers along with many big storage pots. In the lower levels, the amount of 'Classical Dimini' pottery decreases and other decorative motifs are present, albeit in small quantities, while the frequency of storage pots increases. Whether this difference in the composition of the pottery from successive levels in this particular pit reflects changes in the use of space, as suggested by the excavators, chronological differences, or both, demands further examination in the future.

\section{CONCLUSIONS}

In recent years, pottery studies in archaeology have moved beyond the traditional dichotomy between technology-use and social-symbolic (Pritchard and

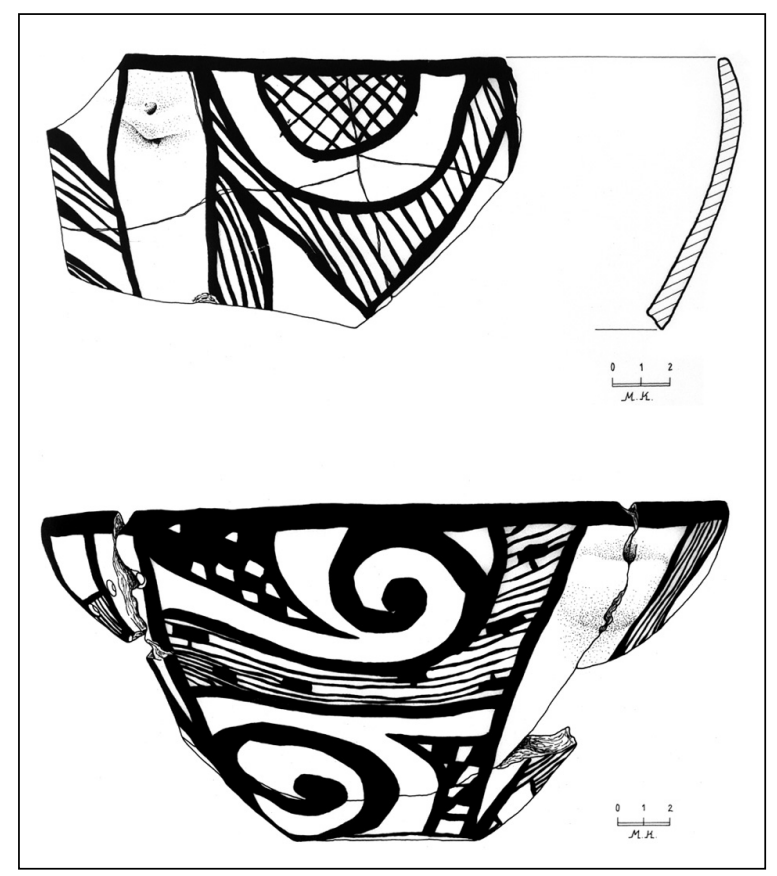

Fig. 8. 'Classical Dimini' pottery from Makriyalos II. van der Leeuw 1984; Stark 1998). The technology and use of pottery and the symbolic and social meaning the pot itself carries, are now regarded from a more anthropological perspective as parts of the same sequence of actions that begin with the manufacture and production of a pot and includes its various uses and, ultimately, its discard (Lemonnier 1993; Skibo 1999). Of course, people are the main participants in these actions. They understand and even change the social meaning of pottery through time, organising the production of a pot not only to meet basic biological needs, but also to represent certain perceptions of dietary traditions or as a means of changing them.

As for Makriyalos II, the history of research in Macedonia and Thessaly shows that, in the later Late Neolithic, stylistic regions are smaller and there is a variety of 'wares' and decorative motifs (Demoule and Perlès 1993.392-393; Perlès and Vitelli 1999. 98). Certain wares are evident over very large geographical areas, as in case of the 'Classical Dimini' pottery, distribution of which reaches Albania, but seems uneven as is indicated by the absence of 'Classical Dimini' pottery at Mandalo and Dispilio. In the case of Makriyalos, the quantity and quality of this particular ceramic category is high. The origin of this

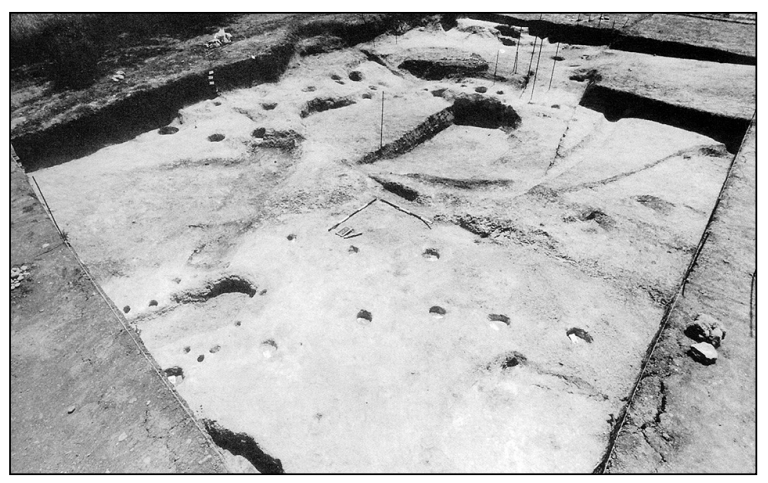

Fig. 9. Pit-dwellings. 
pottery is still unclear and whether pots were imported and so represent products that were exchanged widely, as in the case of obsidian, or were produced locally, is still uncertain. On the other hand, Makriyalos lacks the variety of 'wares' and decoration evident elsewhere in Macedonia, as at Servia (Ridley and Wardle 1979.213-217) or Giannitsa B (Chrysostomou 1996.165), where 'Classical Dimini' pottery is only a part of the decorated pottery assemblage. Decorated pottery at Makriyalos II is dominated by the 'Classical Dimini' styles and only a few other decorative styles occur, such as the incised carinated bowls and some incised pots, but the number of these pots or sherds is limited. The possibility that this is a result of differences in chronological sequence, yet undetected, inside the settlement demands further examination.

In the later Late Neolithic, coarse wares and pottery shapes that could be related to cooking and pottery with traces of repeated use on fire make up a large part of the ceramic assemblage. This perhaps reflects increasing use of pottery in the domestic sphere (Perlès and Vitelli 1999.98). At Late Neolithic Makriyalos II, the preparation of food in particular areas, where there is a concentration of hearths and cooking vessels, seems to be an activity that engaged several individuals or more than one family. On the other hand, the consumption of that food may have been more individualised as the number of cups and some undecorated shallow bowls inside the pits shows. This dual pattern of collective production and individual consumption might suggest that relations between inhabitants were negotiated in everyday life through food. It has been previously been argued that the consumption of food and drink, and of the tableware, played such a role in negotiating social relations in neolithic Greece, particularly between different 'household' groups (Halstead 1995; Andreou, Fotiadis and Kotsakis 1996). Makriyalos

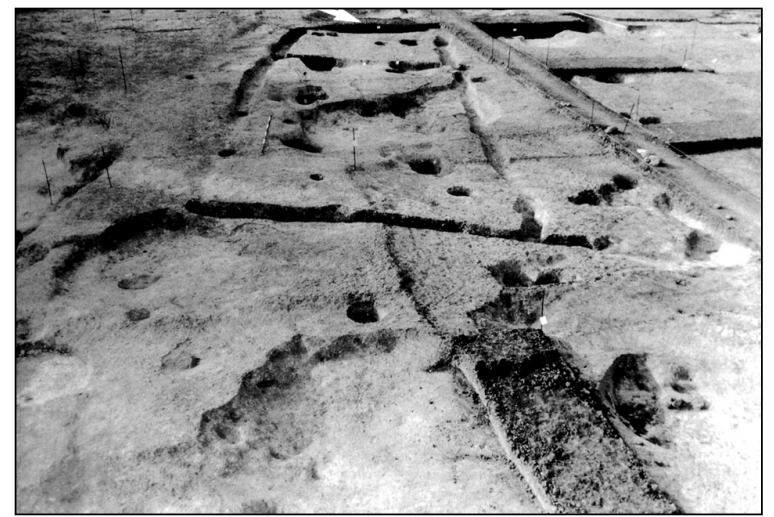

Fig. 11. The apsidal building.

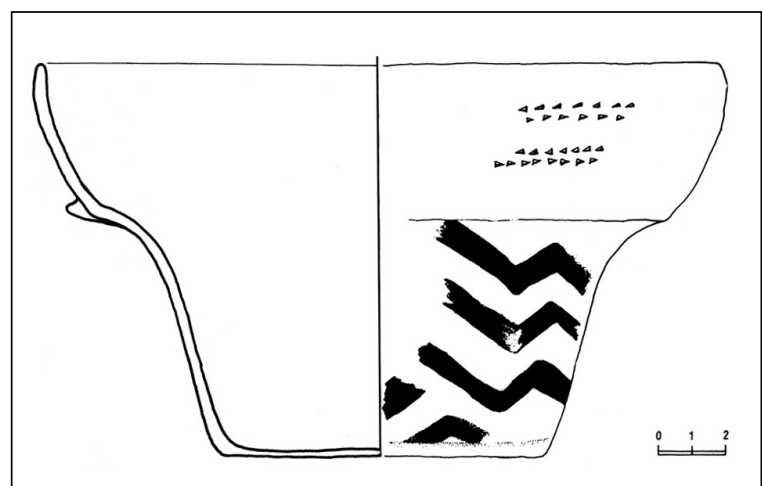

Fig. 10. Incised carinated bowl with painted decoration at the lower part.

II offers the opportunity to explore this role in the rather different social context of a site dominated architecturally by small pit dwellings, suitable for housing only restricted numbers of people.

Finally, while the study of Late Neolithic ceramics has begun in recent years to move beyond the mere concern for chronology, it is clear that little progress has been made in the basic source of the archaeological record, excavation. The extensive excavation at Makriyalos is rare, in terms of Greek archaeology, and more work on this scale is needed to clarify the spatial organization and possible symbolic uses of ceramics and ultimately to treat pottery as an anthropological phenomenon, as a product of human action.

ACKNOWLEDGEMENTS -
I thank Professor Miha Budja for inviting me to the
seminar. Professor K. Kotsakis and my supervisor P.
Halstead strongly encouraged me to participate and
offered valuable suggestions and corrections to the
text. I also thank the excavators, Maria Pappa and
Manthos Besios, for giving me the opportunity to
study the material from Makriyalos II. Photographs
were taken by Arturo Vargas and the photographs
and plans were processed by Nikos Valasiadis.

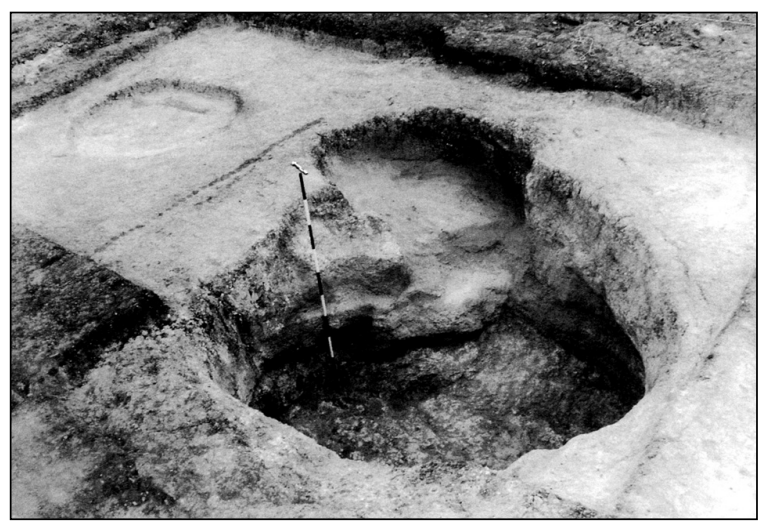

Fig. 12. Pit 24. 


\section{REFERENCES}

ANDREOU S., FOTIADIS M., KOTSAKIS K. 1996. Review of Aegean Prehistory. The Neolithic and Bronze Age of Northern Greece. American Journal of Archaeology 100: 537-597.

CHRYSOSTOMOU P. 1996. I Neolithiki Katoikisi sti Voreia Paraktia Zoni tou Allote Thermaikou Kolpou. To Arxaiologiko Ergo sti Makedonia kai Thraki 10: $159-172$.

GALLIS C. J. 1979. A Short Chronicle of Greek Archaeological Investigations in Thessaly from 1881 until the Present Day. La Thessalie, Actes de la Table-Ronde 21-24 juillet 1975, Lyon: 1-30.

HALSTEAD P. 1995. From Sharing to Hoarding: the Neolithic Foundations of Aegean Bronze Age Society? In R. Laffineur and W.-D. Niemeier (eds.), Politeia: Society and State in the Aegean Bronze Age. Aegaeum 12: 11-20.

HAUPTMANN H. 1981. Die deutchen Ausgrabungen auf der Otzaki-Magula in Thessalien, III: Das späte Neolithikum und das Chalkolithikum. Bonn.

LEMONNIER P. 1993. Technological Choices: Transformation in Material Culture since the Neolithic. London and New York, Routledge.

MILOJČIĆ V. 1960. Hauptergebnisse der deutschen Ausgrabungen in Thessalien 1953-58. Bonn.

MILOJČIĆ V. et al. 1976. Die deutchen Ausgrabungen auf Magulen um Larisa in Thessalien, 1996: Agia Sofia-Magula, Karagyös-Magula, Bunar Baschi. Bonn.

PAPPA M. AND BESIOS M. 1999. The Neolithic Settlement at Makriyalos, Northern Greece: Preliminary
Report on the 1993-1995 Excavations. Journal of Field Archaeology 26: 177-195.

PERLÈS C. AND DEMOULE J. P. 1993. The Greek Neolithic: a New Review. Journal of World Prehistory 7: 355-416.

PERLÈS C. AND VITELLI K. D. 1999. Craft Specialization in the Neolithic of Greece. In P. Halstead (ed.), Neolithic Society in Greece: 96-107.

PRITCHARD A. C. and VAN DER LEEUW S. E. 1984. Introduction: The Many Dimensions of Pottery. In S. E. van der Leeuw and A. C. Pritchard (eds.), The Many Dimensions of Pottery: Ceramics in Archaeology and Anthropology: 1-23.

RIDLEY C. AND WARDLE K. A. 1979. Rescue Excavations at Servia 1971-1973: a Preliminary Report. Annals of the The British School at Athens 74: 185230.

SKIBO J. M. 1999. Pottery and People. In J. M. Skibo and G. M. Feinman (eds.), Pottery and People: $a$ Dynamic Interaction: 1-8.

STARK M. T. 1998. Technical Choices and Social Boundaries in Material Culture Patterning. In M. T. Stark (ed.), The Archaeology of Social Boundaries: 1-11.

THEOCHARIS D. 1973. Neolithiki Ellas. Ethnikis Trapeza tis Ellados. Athens.

1993. Neolithikos Politismos. Morfotiko Idryma Ethnikis Trapezis. Athens.

TSOUNTAS Ch. 1908. Ai Proistorikai Akropoleis Diminiou kai Sesklou. Vivliothiki Arxaiologikis Etaireias 14. Athens.

\section{go back to CONTENTS}

